\title{
Sweeping reforms urged for US energy labs
}

Washington. Comprehensive reform in the way in which the US Department of Energy (DoE)'s 10 national laboratories are managed seems likely to follow the conclusions of a high-level task force, published in Washington last week, that the present system is broken beyond repair

The task force was chaired by Bob Galvin, chairman of Motorola, and calls for the "corporatization" of the national laboratories. This would detach them from direct supervision by the DoE and allow them to operate like industrial corporations, but under the control of a government-appointed board of trustees.

The task force suggests that legislation that places special restrictions on the laboratories should be repealed, and that funding should be allocated by Congress as separate line items for each of their four main missions, national defence, energy, basic research and environment. It also recommends a gradual reduction in federal funding, claiming that the new structure would make the laboratories between 20 and 50 per cent more efficient.

The task force's report paints a picture of 10 laboratories filled with competent people and good equipment but overburdened with hundreds of supervisory staff, hundreds of thousands of pages of unnecessary documentation and auditors "descending daily, often by the dozen" to pursue requirements laid down by the $\mathrm{DoE}$ or Congress.

As the findings of the report sunk in, some laboratory sources expressed concern that Congress is likely to seize upon the task force's assertion that the laboratories could cost less, and cut their \$6-billion budget without bothering to go through the more exacting process of drafting and passing legislation to reduce the regulatory burden on the laboratories and set up a new management structure responsible for their operation.

But congressional staff on both sides warmly welcomed the Galvin report, predicting that, with strong Republican sup-

\section{What the Galvin report said on:}

Governance: “The principal organizational recommendation of this Task Force is that the laboratories be as close to corporatized as is imaginable."

The old model "is broken and should be replaced with a bold alternative. Incremental solutions will not likely provide the major improvements that are, at once, achievable and necessary."

The new model: "We do not presume to know what the precise alternative architecture should be .... One attractive model is a new not-for-profit R\&D corporation or corporations ... governed by a Board of Trustees, consisting primarily of distinguished scientists and engineers and experienced senior executives from US industry."

The British example: "Insight should be gained from the experiences of other nations, including the United Kingdom, which recently has maneuvered a disengagement of several of its government laboratories into a semi-privatized status."

Cost savings: "[Governance reform] could be expected to result in an improvement of between 20 and 50 per cent in the effectiveness of the laboratories themselves, on top of significant staff and overhead savings in the Department [of Energy]."

"Nuclear weapons laboratories "may not be appropriate candidates for transfer to a non-federal governance structure. Some task force members think they are. Some think they are not."

Basic research: "The task force is con- cerned about what appears to have been a significant decline in DoE funding for fundamental research over the past three years, with the prospect of still deeper cuts to follow. The department should sustain and strengthen its support of fundamental science."

Industrial competitiveness: "The industrial competitiveness activities at the national laboratories are unfocused and lack a firm policy foundation. Industrial competitiveness, broadly defined, has no place as a stand-alone mission of the laboratories .... The idea that the laboratories are, or could become, cornucopias of relevant technology for a broad range of industries is a myth."

Environmental management: "the bulk of environmental challenges ... are becoming calcified, and the vast flow of funds into the program acts like an anesthetic, numbing the Department, State regulatory agencies and affected stakeholders, hindering and delaying beneficial change."

Lawrence Livermore National Laboratory (LLNL): "LLNL should retain enough nuclear weapons design competence and technology base to continue its activities in nonproliferation, counter-proliferation, intelligence support, and verification, and to provide independent review [of work at Los Alamos]. LLNL would transfer, as cost-efficiency allows, over the next five years its activities in nuclear materials development and production to the other design laboratory [Los Alamos]."

\section{IMAGE \\ UNAVAILABLE \\ FOR COPYRIGHT REASONS}

\section{Early days: Los Alamos Laboratory has changed dramatically since the Second World War.}

port, legislation to reform the governance of the laboratories could be prepared this year and passed in 1996.

"This is a golden opportunity," says John McTague, vice president of technical affairs at Ford, a former acting science adviser to Ronald Reagan and a member of the Secretary of Energy Advisory Board (SEAB), which formally received the report of the task force last Wednesday. "I think a substantial overhaul is called for," says McTague. "But if it isn't done in 18 months it won't be done at all."

But McTague warned SEAB against following the British example - cited in the report - in which the Atomic Energy Authority laboratory at Harwell, Oxfordshire, is being prepared for privatization. Citing his "long experience" of the Harwell laboratory, he says that it has been "unfortunate to see the long-term science base of that facility wither away".

Galvin says that he sees "corporatization" as meaning that the laboratories would be run by "a corpus body separate from government". The government, he suggests, "could own the corporation if it wants to - but it will turn the governance over to the board of trustees". The concept needs refining, concedes the man who ran Motorola from 1959 to 1990 , and who still chairs the company's executive board: "If I get some encouragement, I'll do a little study to understand better how it can work."

Hazel O'Leary, the energy secretary, who probably expected a less searing indictment of her department when she appointed the task force a year ago, gave its findings a muted welcome. But she initially rejected the "corporatization" of any of the 10 multipurpose laboratories examined by Galvin. "I see that recommendation as the most extreme in the report," she says. "The single-purpose laboratories are natural for that, [but] we wouldn't submit the 10 big laboratories to such an experiment."

The Galvin findings may be adversely affected by unfamiliarity of many new Republican staff in Congress with the task force, who may therefore ignore its 
fiscally and ideologically attractive advice. Supporters of the findings hope that laboratory directors - who dislike existing DoE oversight arrangements, and have good congressional connections - - will help win support for radical reforms.

But Nick Samios, director of the Brookhaven National Laboratory, New York, says that reform could work within the existing, government-owned, contractor-operated (GoCo) system. "I know that a real GoCo will work," he says, claiming that 'corporatization' could damage the laboratories. "I'm not against it," he says. "I just want to see what it is."

Bruce Tarter, director of the Lawrence Livermore National Laboratory in California, which Galvin said should lose its nuclear weapons design capability, issued a statement predicting that Galvin's recommendations "will turn out differently" when evaluated in the context of the entire nuclear weapons programme.

Others suggest even more radical steps. An "Alternative Galvin Report", published by the Military Production Network (MPN), an environmentalist coalition, urged Congress to save $\$ 4$ billion over four years by simply scrapping nuclear weapons research altogether.

"Continued weapons research, development and testing is contrary to stated national goals of 'reducing the global nuclear danger," MPN says. "It's time to end the Manhattan Project."

Colin Macilwain

\section{Gene therapy trial passed in Japan}

Tokyo. Japan's first clinical application of gene therapy was approved earlier this week by a committee of the Ministry of Health and Welfare (MHW).

A research team led by Yukio Sakiyama of Hokkaido University School of Medicine was given permission by the ministry's central assessment committee for gene therapy to carry out clinical research in gene therapy in order to treat a four-year-old boy suffering from adenosine deaminase (ADA) deficiency, an enzyme deficiency that weakens the immune system.

The permission has been given on condition that Sakiyama makes some revisions to the forms used to obtain informed consent from the patient, and that he explains the treatment once more to the boy's parents.

The treatment he plans to use is based on a technique developed five years ago at the US National Institutes of Health (NIH). It involves introducing the ADA gene to the child's T-lymphocytes using a bacterial gene for neomycin resistance.

Sakiyama had initially proposed a slight modification of the technique. But during the approval process this idea was dropped for safety reasons, and he will now use an identical technique to that
London. The British government announced last week that it is to increase funding for 'strategic' science initiatives and for collaboration with industry by $£ 67$ million in the financial year starting on 1 April, equivalent to around five per cent of the total budget of $£ 1,281.7$ million.

Overall, however, the science budget will increase by 3.3 per cent next year, slightly higher than the anticipated rate of inflation. The emphasis being given to strategic initiatives will inevitably mean less money for areas of basic science, and is already causing difficulties in areas such as astronomy (see page 459).

In announcing the allocation of the science budget for 1995-96, David Hunt, minister for science, said that the support for strategic initiatives is intended to promote policies highlighted in the government's science and technology white paper of May 1993, Realising Our Potential.

The money will be used to extend existing schemes to improve interaction with industry - such as the Realising Our Potential Awards (ROPA) scheme - to increase funding for 'underpinning' strategic science in physics, mathematics, medicine and biol-

already successfully used by Michael Blaese of NIH.

Because the retroviral vector to be used in the treatment is not available in Japan, Sakiyama has to obtain approval from the US Food and Drug Administration for the export of the vector by Genetic Therapeutic Inc. of Maryland. As a result, he is not expected to be able to begin treatment until about April.

The approval this week was the last step in a complex process overseen by the MHW committee and another separate committee in the Ministry of Education, Science and Culture. That committee, which was concerned with scientific and safety issues, gave its approval last week.

The MHW committee meeting, which unusually for Japan was open to the press, concentrated on the issue of informed consent, for which Sakiyama is using detailed forms based on a translation of those being used by Blaese in the United States.

There is still little awareness among Japan's medical profession of the Western concept of informed consent, and one additional benefit of the application of gene therapy may be a more rigorous approach to this issue in general medical practice. David Swinbanks

\section{UK shifts research support into 'strategic' initiatives}

ogy, and to enhance 'people-related programmes', including the promotion of the public understanding of science.

Sir John Cadogan, director general of the research councils, has 'ring-fenced' $£ 8$ million of the science budget to insulate the Particle Physics and Astronomy Research Council (PPARC) from fluctuations in its international subscriptions due to changes in exchange rates. PPARC had complained that increases in subscriptions to the European Laboratory for Particle Physics (CERN) and the European Space Agency had left it unable to fund instrumentation and scientists to exploit the contributions. Cadogan said the chief executives of the other councils agreed to the ring-fencing, but were watching the money "like hawks".

The ROPA scheme, which funds researchers who are already working in collaboration with industry, will be one of the main beneficiaries of the new budget, with additional funding of $£ 14.95$ million that will allow it to extend to all six research councils. Cadogan says the outcome will be "blue-skies curiosity-driven research" that will also benefit strategic research.

Another winner in the budget will be the LINK scheme, soon to be relaunched with $£ 3$ million earmarked from the research councils' budgets. The Medical Research Council (MRC)'s genome research programme gets a $£ 3.5$-million fillip.

Chemistry is to retain enhanced support through the Biotechnology and Biological Sciences Research Council (BBSRC), the Engineering and Physical Sciences Research Council (EPSRC) and the Natural Environmental Research Council (NERC), at a total of $£ 7.6$ million.

Physics, mathematics and medicine benefit from $£ 4.4$ million allocated for strategic initiatives, and the BBSRC will receive an extra $£ 2$ million to support research that underpins emerging technologies in bioprocessing and developing 'wealth-creating products' from plants, such as vaccines and biopharmaceuticals.

The Royal Society will also benefit from an increase in the number of its research fellowships from 200 to 255 . Extra funding will also allow it to introduce new fellowships to promote the role of women in science, named after the late Dorothy Hodgkin.

The lack of overall growth in funding has already brought criticism from groups such as the Institute of Professional, Managers and Specialists, the labour union which represents many research council staff. But Hunt described the budget package as "a vote of confidence in the country's engineers, mathematicians, natural and social scientists".

Maggie Verrall 